\title{
Revitalizing Endangered Languages in India: Can Public-Private Partnership (PPP) Work?
}

\author{
Dr. Rajendra Kumar Dash \\ GMR Institute of Technology, Rajam, AP, India
}

\begin{abstract}
:
The UNESCO's latest interactive Atlas of the World's Languages in Danger has identified nearly 2,500 languages endangered out of the 7000-odd languages spoken across the world. With as many as 197 endangered languages among its 600 plus tongues spoken, India tops the list. Further, among the worst hit are the tribal languages. In a country that boasts of linguistic and cultural diversity, language attrition of this scale is arguably a major democratic setback, if not failure. With the death of a language, we lose the life force of a community -- its secret practices, future interpretation of extant literature, environmental knowledge, ancestral world views, and cultural heritage. Alarmed by the UNESCO's 2010 revelation about the country's threatened voices, the Govt. of India has put in place the Scheme for Protection and Preservation of Endangered Languages of India (SPPEL) in 2013 for the revitalization of endangered languages and for a reverse language shift (RLS). The Central Institute of Indian Languages (CIIL), a research and teaching institute of Govt. of India, is overseeing the implementation of the SPPEL (http://www.sppel.org). Under the scheme, Central Universities have been entrusted with the documentation of 500 vulnerable languages that are spoken by less than 10, 000 people each, called "potentially endangered" language by the UNESCO. While critiquing the strategies adopted by SPPEL and allied agencies towards language revitalization (LR) on grounds of pragmatics, this paper argues that the active involvement of an endangered speech community is indispensable in any long-term effort towards preservation and promotion of its language as any LR programme, to be truly successful, requires the convergence of both 'top down' and 'bottomup' approaches and practices, lamentably absent in India. Besides identifying the gap areas in the existing LR strategies, this paper also discusses a conceptual framework namely PPP model that can be designed and implemented by governments or public agencies/institutions, and private stakeholders for the protection, preservation, and promotion of endangered languages in India.
\end{abstract}

Keywords: Endangered language; Language loss; Linguistic diversity; Language death; Reverse language shift; Public-Private Partnership; PPP; SPPEL 


\subsection{Introduction}

Language is not only the chief but also arguably the most indispensable medium of human communication. It plays a vital role in the preservation, maintenance, and promotion of culture "the distinctive ideas, customs, social behaviour, products, or way of life of a particular nation, society, people, or period" (Oxford English Dictionary). In facilitating and serving the people of a particular community to communicate among themselves, a language often shares the fate of a community: it grows when a community prospers; it declines when a community declines; it dies when a community vanishes or its members stop using their language; and it resurfaces again when someone or a group of people, who may or may not belong to the same linguistic community, takes fancy to the "dead language" and popularize (read revitalize) it. This could be more or less the story of all languages in some point of time. According to UNESCO's interactive Atlas of the World's Languages in Danger (hereafter the Atlas; first released in 2001 and regularly updated; last updated on July 5, 2017), in 2001 as many as 900 languages were threatened with extinction, but the number went up to 2500 in 2017. If the recent language trends revealed by the Atlas are a mirror of the state of world's language, metaphors like 'decay', 'moribund' and 'death' characterize most of the languages the world has known and/or used. The Atlas is indicative not only of the dangers to linguistic diversity but also the fatal conditions of many minority languages. In fact language death is not a new phenomenon. The Endangered Language Fund, USA, has rightly observed: "Languages have died off throughout history, but never have we faced the massive extinction that is threatening the world right now" (Cited in Crystal, 2000; p vii). We are in a situation where $50 \%$ to $90 \%$ of the world's languages, including that of India's, will face extinction by the end of the $21^{\text {st }}$ century (Romaine, 2015; Austin, 2008; Brenzinger, 2007) unless and until current rate of extinction is checked. In the face of this unprecedented language crisis, the question before us is: How can we revitalize our endangered languages?

Any fruitful discussion on endangered languages must be based on (a) the state and cause of endangerment of a language or languages, (b) the people or agencies involved in revitalization work, (c) steps undertaken or strategic plans for revitalizing a language or endangered languages, (d) methods, tools and techniques adopted towards language revitalization (LR), and last but not least, (e) the participation of the linguistic minority speech community in revitalization activities. The possibility of reviving a dead language may be remote, but revitalization of dying languages is attainable through proper planning and execution. Efforts at language revitalization have been undertaken by the UNESCO, governments, language research institutes, linguists and language activists, and we have obtained mixed results. The possibility of reviving a dead language may be remote, but revitalization of dying languages is attainable. Language revitalization efforts of the UNESCO, governments, language research institutes, linguists and language activists, have 
produced mixed results and it can be hoped that right strategies and cohesive language planning followed by foolproof implementation will save most of the dying languages of our globe.

\subsection{Language Death: A Global or a Local Issue?}

Language death has alarmed linguists everywhere in the world. Ethnologue (November 2017) claims, "7099 languages are being spoken today and roughly a third of languages are now endangered, often with less than 1,000 speakers remaining" (https://www.ethnologue.com/ guides/how-many-languages); while Crystal (2000, viii) confirms "over half of the world's languages are moribund", and the UNESCO Atlas claims 2500 languages out of 6000 plus languages as endangered. Linguists have noted the death of hundreds of languages in a few hundred years across the globe (Lewis, et al 2013; Biddle, N. \& Swee, H. 2012; Whalen \& Gary, 2012; Wurm, 1991; p 1), particularly languages of small groups which are highly vulnerable (Romaine, 2006, p 31). Supported by statistical data analysis, Krauss (1992: 7) has predicted "the death or the doom of $90 \%$ of mankind's languages". The UNESCO warns that "if nothing is done, half of 6000 plus languages spoken today will disappear by the end of this century [i.e., $21^{\text {st }}$ century]." The death of a language is more than a loss of vocabulary, grammar and literature - it is essentially a loss to or loss of culture. Language loss results in loss of oral literature, cultural identity and intellectual wealth (Mirza \& Sundaram, 2016; Crystal, 2000). In fact language not only holds "a key to the cultural past of a society" (Salzmann, 1998, p. 41) but a fully vital language helps promotion of cultural heritage and together they help the community concerned "claim ownership of their past and future" (Lalonde 2006). Language does not only shape culture, but it is also itself shaped by history, culture, politics (Anderson \& Cater, 2016) and ecology/ environment. Anthropologists and linguists have studied the convergence between nature and language and have observed the similarities in their evolution (Romaine, 2015; Pretty \& Pilgrim, 2008; Mühlhäusler, 2003; Mufwene, 2001; Loh \& Harmon, 1986; Ortner, 1972; MacCormack \& Strathern, 1980; Levi-Strauss, 1962). Ecosystems, cultures and languages are not only interrelated but also a loss of one may result in the loss of the other and/or all. With the a priori that Nature, culture and language form a community's identity and go a long way to shape its fate, this paper proposes in order to keep language, culture, and environment of a community sustainable, i.e., to keep it remain immune to interference from destabilizing external forces, a positive "top-down" (government-to-people) and "bottom-up" (people-to-government) collaboration is inevitable. It argues in favour of a framework to converge the above two approaches to arrest the impending loss of language, cultural identity and ecology of a community, especially that of a linguistic minority community. Integral to this concept, this paper not only proposes but also examines how a programmed action model, namely PublicPrivate Partnership (PPP/P3), can put in place systemic and systematic practices and go a long way to save endangered languages from decline and extinction ensuring the active involvement of a minority linguistic or speech community. 
Linguistic diversity in the globe is a phenomenon to reckon with. More than seven thousand languages are being spoken by billions of people today across the world. However, all languages do not enjoy equal status: some are being spoken by just a handful in small, remote areas with dwindling numbers and some are being used by millions and are considered as global languages. Current news shows that like class struggle, language struggle is the order of the day. Intriguingly enough, whereas almost $50 \%$ of the world's population speaks English, Russian, Mandarin, Hindi and Spanish, many languages across globe have their last one or few members and will die soon. According to a projection (Moore, 2006), as many as 2500 native languages will be extinct by the year 2100 if nothing is done to stop the ongoing process of language loss. Language diversity and cultural diversity are often interrelated and with death of language, more often than not, a culture/subculture gets extinct. Language death is both a global problem and a local crisis. To reverse this alarming trend, linguists and governments substantially agree with UNESCO, that language revitalization and reverse language shift (RLS) are essential.

\subsection{Language Death: India vis-à-vis the Globe}

As of today, 7000-plus languages are spoken across the world and they are unevenly distributed. Crystal (2000, p 4) observes: "The world's languages have a highly uneven distribution: c. 4\% are in Europe; c. $15 \%$ in the Americas; c. $31 \%$ in Africa; c. $50 \%$ in Asia and the Pacific." and according to the UNESCO world's languages are showing a moribund tendency except a few like English, Hindi, French, Mandarin. The findings of UNESCO highlight that "if nothing is done, half of the over 7,000 plus languages spoken today will disappear by the end of the $21^{\text {st }}$ century. With the disappearance of unwritten and undocumented languages, humanity would lose not only a plethora of irreplaceable cultural heritages but also valuable ancestral knowledge embedded in the extinct languages, especially in the indigenous languages" (http://www.unesco.org/ fileadmin/MULTIMEDIA/HQ/ CLT/pdf/ FlyerEndangeredLanguages-WebVersion.pdf). Language vitality reflects not only socio-political or ethnic strength of a speech community, but also the state of democratic rights and social welfare of the people concerned. The UNESCO Atlas of the World's Languages in Danger (last updated July 5, 2017) study finds almost 2,500 endangered languages across the globe out of which 197 belong to India alone: they raise a serious question about the quality of public governance system and point towards the need for better social, economic, administrative, and linguistic policies and planning.

While the Atlas provides analytical reports region-wise by examining the issue of endangerment and classifies languages as per their vitality using labels such as 'Safe' (no threat to the language), 'Vulnerable,' 'Definitely Endangered,' 'Severely Endangered,' 'Critically Endangered' and 'Extinct' (when nobody speaks or remembers the language). As $96 \%$ of the world's languages are spoken by just 4\% of the world's population (Crystal, 2000; p 14), the world is tending to be more and more monolinguistic - a threat to linguistic diversity and 
cultural heritage. India is a major linguistically diverse country, with more than 1,500 "mother tongues" spoken (Census India, 2011), but it is also the home to most of the endangered languages in the world.

According to the UNESCO Interactive Atlas of the World's Languages in Danger (http://www.unesco.org/languages-atlas/), India is the most threatened country (197 languages), followed by USA (191), China (144), and Indonesia (143). Among the 197 endangered languages in India, 81 are "vulnerable" followed by "definitely endangered" (63), "severely endangered" (6), "critically endangered" (42) and "already extinct" (5). The cause of concern is that $96 \%$ of the Indian languages are under the threat of extinction (The Wire, 08/06/2017). No doubt Hindi is India's $1^{\text {st }}$ and the world's fourth most spoken language (652 million plus) with 438 million plus L1 speakers and 214 million L2 speakers; Bengali occupies India's 2nd and world's 10th most spoken language position with L1 and L2 speakers of 245 million (including 19 million in Bangladesh), and Telugu occupies India's 3rd and world's 17th most spoken language position with a total 92 million speakers ("Summary by language size," Ethnologue. Retrieved on 14-11-2017). In spite of some Indian languages being in the list of the major languages spoken in the world, the fact remains that India owns the largest numbers of endangered languages. Officially there are 122 languages in India, but the Peoples Linguistic Survey of India has identified 780 languages, of which 50 have gone extinct in the past five decades. The dismal state of our languages, especially the tribal ones, does not bode well for India, which is also the largest democracy in the world and constitutionally bound (e.g., Article 29 \& 244) to safeguard ethnic and linguistic diversity. Linguistically speaking, India has a dubious status in language vitality: when some languages (major state languages) are prospering in terms of growth of users, linguistic use (vocabulary, phonology, morphology, commercials), literature enrichment (translation included), web presence and interaction, majority of minor languages are moving toward extinction.

\subsection{The State of the Languages in India Statewise}

The Constitution of India recognizes 22 languages including Hindi and English, the two official languages of the union. With $41 \%$ of people speaking Hindi, it is the most widely spoken language in India the people of which speak in hundreds of tongues dispersed through the length and breadth of this country. According to UNESCO, 197 languages in India are reported to be endangered of which 81 are vulnerable followed by definitely endangered (63), severely endangered (6), critically endangered (42) and already extinct (5). Andaman and Nicobar Islands top the list with 11 critically endangered languages, mainly tribal dialects. Among the states, it is Manipur with seven languages, followed by Himachal Pradesh with 4 endangered languages. According to (UNESCO), any language spoken by less than 10,000 persons is considered "potentially endangered" and India has more than 100 such languages. Of course, not every 
potentially endangered language necessarily faces the threat of immediate extinction, but is under immediate need for revitalization.

Unfortunately, in the absence of proper and conclusive surveys on the number of languages spoken in India, we only get broad ideas and trends on languages rather than clear pictures on the state of language vitality in India, whether it is from government records or UNESCO records. In this connection, the observations of Prof. Panchanan Mohanty, the Coordinator of Centre for Endangered Languages and Mother Tongue Studies in the University of Hyderabad, are quite noteworthy here:

"According to 2001 census, we have only 122 languages in this country. But the same report says that India has 1635 mother-tongues. In 1971 the Government of India decided not to list those languages with less than 10000 speakers. In India, 96.56 per cent of people speak in the 22 languages scheduled in Indian constitution. Just 3.44 per cent of our countrymen speak all the remaining 1613 mother tongues. It effectively implies that any language that does not find a mention in the census list should be considered as endangered. It is a very sad situation indeed. If these languages are not conserved, our linguistic diversity will vanish." (Reported by The Times of India, Feb. 22, 2017)

The noted linguist further observes:

"Nobody has carried out a comprehensive survey of all the endangered languages in this country till date. So we do not know for sure how many languages in the country are endangered. In fact, in my recent field work I discovered a new Dravidian language in Odisha. Its phonology is very different from any other Dravidian languages we know of. There are many languages yet to be discovered." (Reported by The Times of India, Feb. $22,2017)$

Language research is an ongoing process: it may have a beginning, but no definite end. At least this observation is valid in language revival as well as language revitalization processes. Clear and comprehensive data is a major obstacle in the process of revitalization of endangered languages; however, it is more or less an ideal situation, at least in India. So notwithstanding the incompleteness of data on Indian languages, a list of languages and their current status as of today can be compiled from the available data as follows: 


\begin{tabular}{|c|c|c|c|c|}
\hline \multicolumn{5}{|c|}{ Major Languages vis-à-vis Endangered Languages Spoken in India } \\
\hline $\begin{array}{l}\text { Sl. } \\
\text { No. }\end{array}$ & Name of State & $\begin{array}{l}\text { Major } \\
\text { Language(s) } \\
\text { Spoken }\end{array}$ & $\begin{array}{l}\text { Other Languages } \\
\text { Spoken }\end{array}$ & Endangered Languages \\
\hline 1 & Andhra Pradesh & Telugu & $\begin{array}{l}\text { Urdu; Hindi; Tamil; \& some } \\
\text { minor languages }\end{array}$ & $\begin{array}{l}\text { Gadaba or Gutob; Gondi; } \\
\text { Gormati; Gutaba Gadaba; } \\
\text { Kolami; Konda-Dora or } \\
\text { Porja; Koya; Kui; } \\
\text { Kupia or Valmiki; Kuvi; } \\
\text { M\&a; Mannadona; Parji; } \\
\text { Reli (extinct); Savara; } \\
\text { Yerakula }\end{array}$ \\
\hline 2 & $\begin{array}{l}\text { Arunachal } \\
\text { Pradesh }\end{array}$ & English & $\begin{array}{l}\text { Nepali; Hindi; Bengali; } \\
\text { Assamese; \& some minor } \\
\text { languages }\end{array}$ & $\begin{array}{l}\text { Adi; Tangam; Milango; Nah; } \\
\text { Puruik; Khowa or Bugun; } \\
\text { Meyor; Miji; Singhpo; Aka or } \\
\text { Hrusho; Nishi, Wancho, } \\
\text { Sherdukpen, Zaiwa, Mra, Na, } \\
\text { Tangam }\end{array}$ \\
\hline 3 & Assam & Assamese & $\begin{array}{l}\text { Bodo; Bengali; Hindi; } \\
\text { Nepali; \& some minor } \\
\text { languages }\end{array}$ & $\begin{array}{l}\text { Karbi; Tiwa; Tai Nora; Tai } \\
\text { Rong; Bodo; Misings; Deoris; } \\
\text { Biate; Apatani; Nishi, }\end{array}$ \\
\hline 4 & Bihar & Hindi; Urdu & $\begin{array}{l}\text { Maithili; Bhojpuri; } \\
\text { Magadhi; Bajjika; Angika; } \\
\text { Vajjika/ Brajjika/Bajjika }\end{array}$ & $\begin{array}{l}\text { Majhi; Kudmali; Musasa; } \\
\text { Birhor; Chero; Birjia; Turi }\end{array}$ \\
\hline 5 & Chhattisgarh & $\begin{array}{l}\text { Chhattisgarhi/ } \\
\text { Hindi }\end{array}$ & Bengali \& Odia & Bhunija \\
\hline 6 & Goa & Konkani & $\begin{array}{l}\text { English, Hindi; Marathi } \\
\text { Kannad; Urdu }\end{array}$ & Portuguese \\
\hline 7 & Gujarat & Gujarati & $\begin{array}{l}\text { Hindi; Sindhi; English, } \\
\text { Marathi; Urdu }\end{array}$ & $\begin{array}{l}\text { Mangeli, Karwa, Dungri } \\
\text { Bhili, Nayki, Kathodi, } \\
\text { Kathali, Talaviya Rathod, Sidi }\end{array}$ \\
\hline 8 & Haryana & Hindi & Punjabi \& Urdu & Korvi \\
\hline 9 & Himachal Pradesh & Hindi \& Pahari & Punjabi \& Nepali & $\begin{array}{l}\text { Shirmau; Tinan, Bharmauri, } \\
\text { Chinali, Baghati, Jad, } \\
\text { Kanashi, Handuri, Pangvali, } \\
\text { Sirmaudi, Mandiyali, Mahasu } \\
\text { Pahari, Chambiyali, Bilaspuri }\end{array}$ \\
\hline 10 & Jammu \& Kashmir & Urdu & $\begin{array}{l}\text { Dogri; Kashmiri; Ladakhi; } \\
\text { Dadri; Punjabi; Hindi }\end{array}$ & $\begin{array}{l}\text { Khash, Hassadi, Zangsdkr, } \\
\text { Dargari, Dogri, Gojri, } \\
\text { Badherwah }\end{array}$ \\
\hline 11 & Jharkhand & Hindi & Santali; Bengali \& Urdu, & Korwa, Asuri, Birhori, \\
\hline
\end{tabular}




\begin{tabular}{|c|c|c|c|c|}
\hline & & & $\begin{array}{l}\text { Mundari, Santhali, Kurukh, } \\
\text { Ho, Kharia, Kurmali and } \\
\text { Nagpuri }\end{array}$ & $\begin{array}{l}\text { Korwa, Sabari, Malto, } \\
\text { Angika, Santhali, Khortha }\end{array}$ \\
\hline 12 & Karnataka & Kannada & $\begin{array}{l}\text { Urdu; Telugu; Marathi; Tamil } \\
\text { Konkani, Kodava and Tulu }\end{array}$ & $\begin{array}{l}\text { Koraga, Irula, Soliga, Badaga, } \\
\text { Yerava, Gouli, Bettakuruba, } \\
\text { Jenukuruba, Siddi, Hakki } \\
\text { Pikki, Kutiya, Toda, Bellari, } \\
\text { Kuruba }\end{array}$ \\
\hline 13 & Kerala & Malayalam & None & $\begin{array}{l}\text { Malasar, Ara Nandan, } \\
\text { Moopan, Maduga, Paliya, } \\
\text { Mannan, Eravallan }\end{array}$ \\
\hline 14 & Madhya Pradesh & Hindi & $\begin{array}{l}\text { Marathi,Urdu,Malvi, Nimadi, } \\
\text { Bundeli, Bagheli }\end{array}$ & $\begin{array}{l}\text { Bhilodi, Gondi, Kalto, Malvi, } \\
\text { Nimadi, }\end{array}$ \\
\hline 15 & Maharashtra & Marathi & Hindi; Urdu \& Gujarati & $\begin{array}{l}\text { Naiki, Nihali, Korku, } \\
\text { Khandeshi }\end{array}$ \\
\hline 16 & Manipur & Manipuri & Nepali; Hindi \& Bengali & $\begin{array}{l}\text { Aka, Zo, Thadou, Vaiphei, } \\
\text { Aimol, Koireng, Lamgang, } \\
\text { Langrong, Purum, Tarao }\end{array}$ \\
\hline 17 & Meghalaya & $\begin{array}{l}\text { English; Khasi; } \\
\text { Garo }\end{array}$ & Hindi; Bengali; Jaintia; Nepali & Ruga \\
\hline 18 & Mizoram & Mizo & $\begin{array}{l}\text { English; Hindi; Bengali; } \\
\text { Nepali }\end{array}$ & Tiddim Chin \\
\hline 19 & Nagaland & English & $\begin{array}{l}\text { Bengali; Hindi; Nepali; Ao; } \\
\text { konyak; Angami; Sema; Lotha }\end{array}$ & Yacham, Yimchungru \\
\hline 20 & Odisha & Odia & Hindi; Telugu \& Santali & Manda, Pengo, Parji \\
\hline 21 & Punjab & Punjabi & Hindi, Urdu, English & Rai Sikh, Sansi, Odi \\
\hline 22 & Rajasthan & Hindi & $\begin{array}{l}\text { Marwari: Punjabi; Rajasthani } \\
\text { \& Urdu, Malvi, Dhundhari, } \\
\text { Harauti, Mewari, Mewati, } \\
\text { Ahirwati, Shekhawati, Wagdi, } \\
\text { Bagri, Nimadi }\end{array}$ & Hadoti \\
\hline 23 & Sikkim & Nepali & $\begin{array}{l}\text { Hindi; Bengali; Bhutia; } \\
\text { Lepcha; Limbu }\end{array}$ & Lepcha, Bhutia, Limbu \\
\hline 24 & Tamil Nadu & Tamil & Telugu; Kannada \& Urdu & $\begin{array}{l}\text { Eravallan, Toda, Jenu } \\
\text { Kurumba, Kurumba, Malasar, } \\
\text { Kota, }\end{array}$ \\
\hline 25 & Telangana & Telugu \& Urdu & Several minor languages & $\begin{array}{l}\text { Kolami, Koya, Gondi, Kuvi, } \\
\text { Kui, Yerukala, Savara, Parji, } \\
\text { Kupia }\end{array}$ \\
\hline 26 & Tripura & Bengali & $\begin{array}{l}\text { Hindi; Tripuri; Manipuri; } \\
\text { Kakborak }\end{array}$ & Tiwa (Ladung) \\
\hline 27 & Uttar Pradesh & Hindi & Urdu & Awadhi, Brajbasha \\
\hline 28 & Uttarakhand & Hindi & Urdu; Punjabi \& Nepali & $\begin{array}{l}\text { Sanskrit, Bangani, Garhwali, } \\
\text { Kumauni, }\end{array}$ \\
\hline 29 & West Bengal & Bengali & Hindi; Santali; Urdu; Nepali & Dhimal; Sobor; Goya; Tharu; \\
\hline
\end{tabular}




\begin{tabular}{|c|c|c|c|c|}
\hline & & & & $\begin{array}{l}\text { Jalda; Asur; Hemal; Bedia, } \\
\text { Kurukh, Toto, Turi }\end{array}$ \\
\hline $\begin{array}{l}\text { Sl. } \\
\text { No. }\end{array}$ & $\begin{array}{l}\text { Name of Union } \\
\text { Territory }\end{array}$ & $\begin{array}{l}\text { Major } \\
\text { Language(s) } \\
\text { Spoken }\end{array}$ & $\begin{array}{l}\text { Other Languages } \\
\text { Spoken }\end{array}$ & Endangered Languages \\
\hline 1 & $\begin{array}{l}\text { Andaman and } \\
\text { Nicobar Islands }\end{array}$ & Bengali & $\begin{array}{l}\text { Hindi, Tamil, Telugu, } \\
\text { Nicobarese \& Malayalam }\end{array}$ & $\begin{array}{l}\text { Jarawa, Tehniu, Luro, Muot, } \\
\text { Sanenyo, Shompen, Great } \\
\text { Andamanese, Lamongse, } \\
\text { Muot, Onge, Pu, Sentilese, } \\
\text { Takahanyilang }\end{array}$ \\
\hline 2 & Chandigarh & Punjabi & Hindi and English & Rai Sikh, Sansi and Odi \\
\hline 3 & $\begin{array}{l}\text { Dadra and Nagar } \\
\text { Haveli }\end{array}$ & Gujarati & $\begin{array}{l}\text { Hindi, Konkani and Marathi } \\
\text { Gujarati, Bhili, Bildoli }\end{array}$ & $\begin{array}{l}\text { Warlis, Dhodia Kokna tribal } \\
\text { languages }\end{array}$ \\
\hline 4 & Daman and Diu & Gujarati & $\begin{array}{l}\text { Marathi, Hindi, Bildoli or } \\
\text { Bhili, Konkani, English }\end{array}$ & Portuguese \\
\hline 5 & Delhi & Hindi & English & NOT KNOWN \\
\hline 6 & Lakshadweep & Malayalam & English, Divehi & $\begin{array}{l}\text { Muduga, Malaveda, } \\
\text { Kanikkar, Kakkala, Mahl }\end{array}$ \\
\hline 7 & Puducherry & Tamil & Telugu, Kannada and Urdu & \\
\hline
\end{tabular}

Alerted by the UNESCO revelation, the Ministry of Human Resource Development (MHRD) of Government of India (GOI) has initiated a scheme in 2013 for the galvanization of endangered languages, known as the Scheme for Protection and Preservation of Endangered Languages of India (SPPEL) (for details, visit http://www.sppel.org). Under the SPPEL, which has been effective since February, 2014, the CIIL works on protection, preservation and documentation of all the mother tongues/languages of India spoken by less than 10,000 speakers keeping in mind 'the degree of endangerment and reduction in the domains of usage.' The languages which are spoken by less than 10,000 speakers or languages which are not linguistically studied earlier are chiefly considered to be documented in this Government of India scheme. Presently, 117 languages have been listed for the documentation, in the form of grammar, dictionary and ethno-linguistic profiles (http://www.sppel.org/about-us.aspx). The CIIL and MHRD have allocated funds to Central Universities in India to carry forward the revitalization of endangered languages. The CIIL, which proclaims that it is "charged with the 
responsibility to serve as a clearing house on all matters relating to the development of Indian languages in this country and abroad", also laments that:

One of the serious problems faced equally by scholars as well as other persons involved in language related activities is the lack of up-to -date information on work done, being done or envisaged to be done, the scholars and the institutions engaged in such activities, the publishers and other agencies from "where such material or information can be obtained. (http://www.ciil.org/RTIFunction.aspx)

A study of the measures adopted by these LR agencies shows that the methods involved in the preservation work is mainly field research by individual and groups of linguists who work using Survey, Case study and Interview tools, among others. However, this researcher strongly believes that language revitalisation cannot be done in isolation; in other words, the active participation of the affected language community is a must to make the effort successful. Besides, one has to remember that it is not a stop gap arrangement; rather language vitalization is a continuous process. The problem of lack of community participation is actuated by lack of an institutional framework to work with the public/community which is randomly engaged by the researcher concerned on ad hoc basis whereas a proper, field-based, regular, and formal institutional framework would be many times more effective. Against this problem, the present researcher argues for a well-tested framework or a model that is already in practice but never used in the field of language endangerment, i.e. the Public-Private Partnership (PPP) model. This model is well-developed in India and has been implemented by Govt. of India/State governments with public (https://www.pppinindia.gov.in/).

PPP is defined as "an arrangement between a government / statutory entity / government owned entity on one side and a private sector entity on the other, for the provision of public assets and/or public services, through investments being made and/or management being undertaken by the private sector entity, for a specified period of time, where there is well defined allocation of risk between the private sector and the public entity and the private entity receives performance linked payments that conform (or are benchmarked) to specified and predetermined performance standards, measurable by the public entity or its representative" (https://www.pppinindia.gov.in/toolkit/ports/module1-oopi-infra-wipii.php?links=oopiila). This paper argues that PPP will be the most suitable mode in which an effective LR action plan can be formulated and implemented. Coming back to endangered languages, it is a fact that revitalization work cannot be carried out successfully without involving the people or the community whose language has been facing the threat of extinction.

Community involvement is an indispensable requirement for reversing language loss, which happens when people stop transmitting their language intergenerationally (Rhydwen, 1998). Language being a vital aspect of culture, the death of a language is an irreparable loss for 
humanity as well. In this connection, UNESCO Director-General Koïchiro's observations are worth quoting:

\begin{abstract}
"The death of a language leads to the disappearance of many forms of intangible cultural heritage, especially the invaluable heritage of traditions and oral expressions of the community that spoke it - from poems and legends to proverbs and jokes. The loss of languages is also detrimental to humanity's grasp of biodiversity, as they transmit much knowledge about the nature and the universe." (UN News Centre, 19 February 2009; http://www.un.org/apps/news/story.asp?NewsID=29950)
\end{abstract}

To sustain linguistic diversity as well as cultural diversity, language revitalization and reverse language shift are well-established methods. The very fact that countries with most linguistic variety --- India, the United States, Brazil, Indonesia and Mexico --- are also the ones with most endangered languages indeed speaks volumes not only of the impending national/global loss but also the need for a linguistic-cum-administrative mechanism to reverse the trend. India being the world's most endangered languages region has started working on revitalization of its vulnerable languages through the SPPEL, but the work is rather slow and more academic-oriented. In the coming sections, we shall analyze the factors leading to language loss in India, the nature and scope of working of the SPPEL, and discuss why a more pragmatic approach is required to reverse the language shift and the need for a new national language policy in which PPP can be a viable model for the preservation and promotion of endangered languages. As language policies change over time, the PPP can become an approved framework for revitalization of vulnerable languages by defeating the very forces of language endangerment.

\title{
5.0 Universal Factors contributing to Language Endangerment
}

The UNESCO engaged the services of some stalwart linguists to fix the criteria to judge the vitality of languages. The UNESCO Ad Hoc Expert Group on Endangered Languages (2003) decided upon nine parameters: (1) Intergenerational language transmission, (2) Absolute number of speakers, (3) Proportion of speakers within the total population, (4) Shifts in domains of language use, (5) Response to new domains and media, (6) Availability of materials for language education and literacy, (7) Governmental and institutional language attitudes and policies including official status and use, (8) Community members' attitudes toward their own language, and (9) Amount and quality of documentation. 


\section{SOCIAL SCIENCES IN THE 21ST CENTURY}

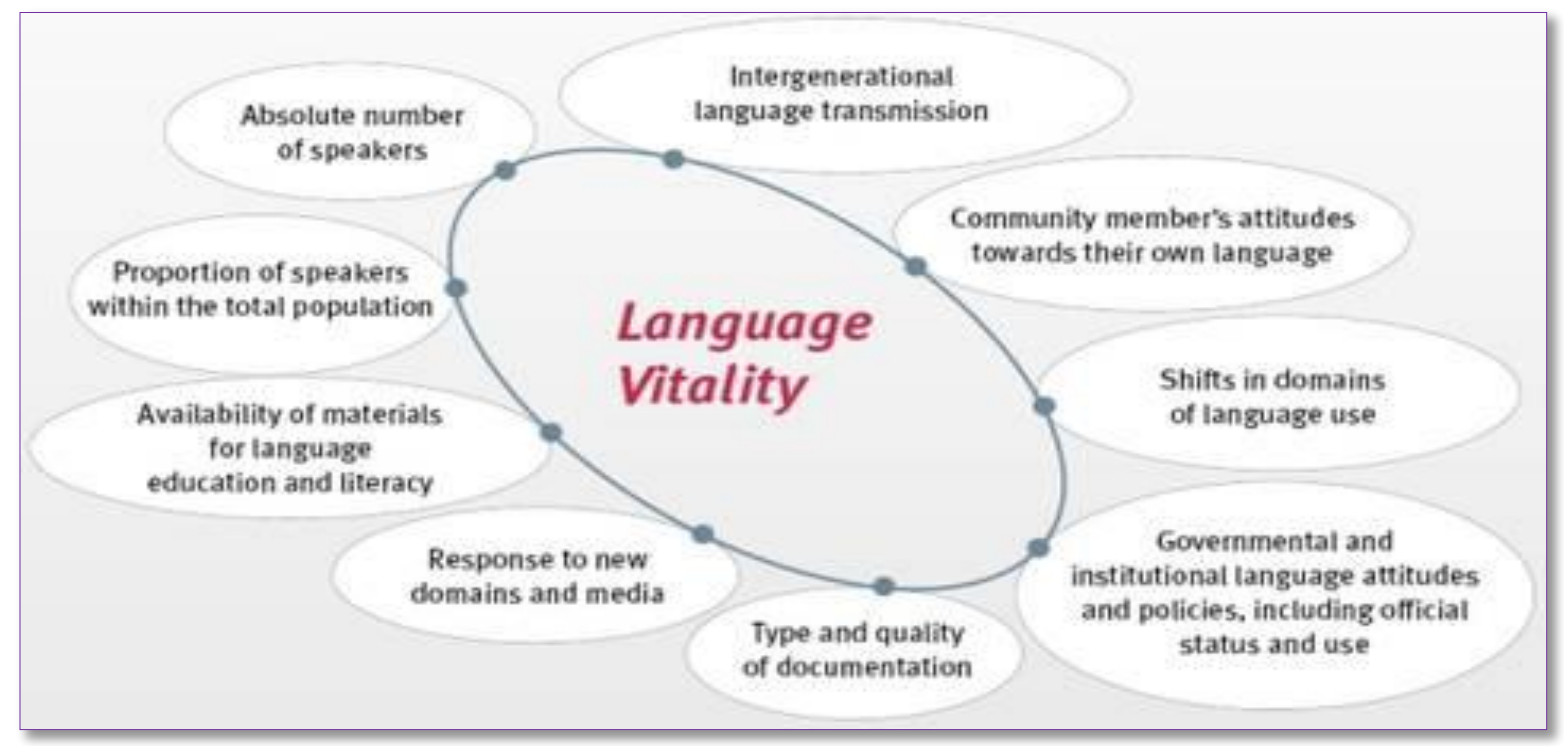

Figure 1: Source: UNESCO Ad Hoc Expert Group on Endangered Languages identified 9 factors to assess vitality of a language, in their seminal paper, "Language Vitality and Endangerment" (2003)

Based on UNESCO's Language Vitality and Endangerment framework, six degrees of vitality/endangerment are established based on the above nine factors, of which 'intergenerational transmission' is the most crucial one.

\begin{tabular}{|l|l|}
\hline \multicolumn{2}{|l|}{ Levels of Language Vitality in UNESCO Atlas of the World's Languages in Danger } \\
\hline Degree of endangerment & Intergenerational Language Transmission \\
\hline Safe & $\begin{array}{l}\text { Language is spoken by all generations; intergenerational } \\
\text { transmission is uninterrupted }\end{array}$ \\
\hline Vulnerable & $\begin{array}{l}\text { Most children speak the language, but it may be restricted to } \\
\text { certain domains (e.g., home) }\end{array}$ \\
\hline Definitely endangered & $\begin{array}{l}\text { Children no longer learn the language as mother tongue in } \\
\text { the home }\end{array}$ \\
\hline Severely endangered & $\begin{array}{l}\text { Language is spoken by grandparents and older generations; } \\
\text { while the parent generation may understand it, they do not } \\
\text { speak it to children or among themselves }\end{array}$ \\
\hline Critically endangered & $\begin{array}{l}\text { The youngest speakers are grandparents and older, and they } \\
\text { speak the language partially and infrequently }\end{array}$ \\
\hline Extinct & There are no speakers left \\
\hline $\begin{array}{l}\text { Note: 'Safe' languages are not included in the Atlas; 'Extinct' languages are included in the Atlas if } \\
\text { presumably extinct since the 1950s. }\end{array}$ \\
\hline
\end{tabular}




\subsection{Visible and Invisible Forces Responsible for Language Endangerment}

\section{Factors endangering languages in India}

Several factors have been identified to be responsible for causing language death or at least language endangerment in India: some of them are visible and some of them are subtle. Due to constraints of space and possibility of distraction from our set objective, the threatening factors are discussed briefly without examples. The factors responsible for endangerment of Indian languages can be listed and discussed as follows: (1) 'Love of Father Tongue' Syndrome,

(2) Poverty and Illiteracy, (3) Myopic Language Policy and Planning, (4) The Politics of Language in India, (5) Religious Conversion, (6) Negative Impact of Globalization on Traditional Culture, Ecology and Languages, (7) Migration and Immigration, (8) Poor Digital Presence \& Interactiveness, (9) Mediocracy, and (10) Poor Media Control.

\section{1 'Love of Father Tongue' Syndrome}

Majority of people in India believe that the popularity of English, especially after LPG, is causing a blow to indigenous languages due to language shift from mother tongue to English. This insinuation is common to all post-colonial countries. However, Christopher Moseley, an Australian linguist and editor-in-chief of the UNESCO Atlas of the World's Languages in Danger, has something different to say:

"It would be naïve and oversimplifying to say that the big ex-colonial languages, English, or French or Spanish, are the killers, and all smaller languages are the victims. It is not like that; there is a subtle interplay of forces, and this Atlas will help ordinary people to understand those forces better." (Italics are added for emphasis.)

We cannot summarily agree with Moseley that English does not have any role whatsoever in endangering native tongues as in the US the English-only approach has created hierarchies among languages and undermined linguistically minor ones. However, we cannot say this is exactly the case in India. Love for English and other employment generating languages have weaned away many speech communities from their mother tongues. Technically speaking, "Mother tongue is the language spoken in childhood by the person's mother to the person. If the mother died in infancy, the language mainly spoken in the person's home in childhood will be the mother tongue" (Language Division of India: http://1si.gov.in/ MTSI_APP/ (S(ifg2o355pbzcyx3zjpxhrd55))/default.aspx). We may use the phrase 'father tongue' to describe the displacing languages in a particular context. UNESCO, which perceived this trend, has in 1999 declared February 21 as International Mother Language Day to revive peoples' love for their mother tongues. 
Though English is an elite language in India and Indians consider it to be a prestige to speak and write in this foreign language, the major official language of India (Hindi) and many regional languages have successfully counter-balanced the dominance of English, which along with Hindi is an official language in India. In some provinces/states in India, the major state language is de jure or de facto official language in spite of English. Thus it will be erroneous to assume that among all the languages in India English is a big shark and the indigenous languages are mere minnows just to be eaten away by the shark over time. If we observe the diglossic use of Hindi and English in the Bollywood (Hindi) movies, we may come to the conclusion that English in India has benefitted Hindi rather than endangering it. In an age of machine translation and social media, English should be seen more as a friendly language rather than a hostile language by indigenous languages. If we rely on the data from the People's Linguistic Survey of India (PLSI), over the last 50 years, the world's Hindi-speaking population has increased from 260 million to 420 million, but also 250 languages in India have disappeared in the last 50 years. So, we have got to identify the other forces behind endangered languages besides English. Taking the lead from Moseley, the government(s) and linguists must identify the forces and how they subtly interplay to obliterate languages in India. These forces are supposed to be both internal as well as external (Yang, 2000). As this paper's scope does not allow us for a full-scale investigation into identifying the forces behind language endangerment and unearth the subtle interplay of these forces, we will attempt to briefly list what we consider to be the major culprits of language death in India.

\subsection{Poverty and Illiteracy}

This researcher's conviction that poverty is one of those noxious forces which destabilize a linguistic minority community and force its members for language shift with a view to having better economic opportunities, such as employment and business transactions. The link between poverty and language endangerment has been studied and research has confirmed it from time to time (Nettle \& Romaine, 2000; Sayre, 1999; Robinson, 1996). If we consider the continent of Africa, the most linguistically diverse continent in the world (over one billion people speak over 2,000 different spoken languages), it becomes clear how poverty affects language even as socioeconomically disadvantaged minorities shift to other languages for better socio-economic benefits and resources (Batibo, 2005, 2009). Romaine (2015) confirms this finding in the following words, “...the vast majority of today's threatened languages and cultures are found among socially and politically marginalized and/or subordinated national and ethnic minority groups." She further asserts that "the speakers of most of the languages at greatest risk of disappearing over the next few decades are very often also the poorest of the poor at the bottom of the economic ladder, and at the margins of a rapidly globalizing world." Poverty is inalienable from illiteracy, which perpetrates the vicious cycle of poverty. Poverty is the major reason 
behind urbanization and urbanization has contributed much to the extinction of India's 20\% of languages in the past five decades. This is the case in India.

According to the World Bank, India has highest number of people living below international poverty line even as 224 million people in India are abysmally poor. What's more deplorable is the fact that poverty is highest among the scheduled tribes (STs) of India. In the endangered languages of the world, India ranks $1^{\text {st }}$ with 191 languages in the Atlas and among them 6 tribal languages are severely endangered, 42 are critically endangered, and five languages have already become extinct (UNESCO, 2010). Currently 8.2\% of the Indian population speaks in tribal languages and according to the Atlas most of them are endangered to some extent. Poverty and illiteracy are the chief dangers to cultural as well as linguistic diversity. Those who argue that extinction of language is inevitable as people would prefer to shift to other languages to lead a more prestigious (fashionable?) life which their mother tongues cannot provide them. Of course, language development is related also to the socio-economic development of the 'marginalized' speech community. And education can equip them for a better life even with their mother tongue. It is, however, deplorable that children of most tribal communities are not getting their education in their mother tongues (Mishra, 2011). This fact has been highlighted in the Report of the High Level Committee on Socio-Economic, Health and Educational Status of Tribal Communities of India (May 2014) issued by the Ministry of Tribal Affairs, Government of India, under the chairmanship of Prof. Virginius Xaxa: "Most of the tribal communities in India have their own mother tongue. But in most of the States, officia/regional languages are used for classroom teaching and these are not understood by the tribal children at primary level of schooling" ( $p$ 184). They are under compulsion to undermine their own language, history, culture. As history, culture and politics have tremendous impact on shaping language (Andresen \& Carter, 2016; p 324), the very fundamental rights of the minority linguistic groups of indigenous people are indirectly compromised. In this connection, the observations of Prof Omkar N. Koul, former director of the Central Institute of Indian Languages (CIIL), are thoughtprovoking: “... certain languages face the threat of extinction as they are not used as mediums of instruction in educational institutions, government transactions and the media. ... If a language is not getting sufficient role in these three domains, there is every possibility that it will die. The fate of a number of languages in India is the same as they are neither used for education or governance purpose" (http://www.indiantribalheritage.org/?p=6039). The current practice undermines the Indian constitution guidelines and provisions, as we shall see, too.

Article 19(5) of the Constitution of India states that a cultural or linguistic minority has a fundamental right to conserve its language and culture. The Article 29 (1) of the Indian constitution clearly states that 'Any section of the citizen residing in the territory of India or any part thereof having a distinct language, script or culture of its own shall have the right to conserve the same'. Further, Article 350 (A) provides that 'the state shall provide adequate facilities for instruction in the mother tongue at the primary state of education to children 
belonging to linguistic minority groups....". The Govt. of India is further bound by Article 244 of the constitution for the preservation of the tradition and culture of the Scheduled Tribes as well as by the Right of Children to Free and Compulsory Education Act, 2009 to provide free education to tribal children.

Most of the tribes in India belong to poor states. For example, tribals make about $25 \%$ of the population of Odisha. Even after more than seven decades of independence of the country, the economic status of tribals are not much better as they have been either left to isolation or have become victims of cultural, political, educational, economic marginalization and globalization. The erosion of the tribal languages and cultures owe to poverty, illiteracy, and state apathy. The fact remains that any language revitalization effort should truly empower the minority linguistic community must take care of its socio-economic and educational development. Thus both government and people must come forward to cooperate with each other to save endangered languages. We shall examine the possibility of convergence of the top-down and bottom-up under the PPP model, after having discussed the other forces responsible for language endangerment in India.

\subsection{Myopic Language Policy and Planning (LPP)}

There is no doubt that a multi-linguistic country like India should have a robust language policy. According to the claims of MHRD, Govt. of India, India celebrates linguistic diversity:

The Language Policy of India relating to the use of languages in administration, education, judiciary, legislature, mass communication, etc., is pluralistic in its scope. It is both languagedevelopment oriented and language-survival oriented. The policy is intended to encourage the citizens to use their mother tongue in certain delineated levels and domains through some gradual processes, but the stated goal of the policy is to help all languages to develop into fit vehicles of communication at their designated areas of use, irrespective of their nature or status like major, minor, or tribal languages. The policy can accommodate and ever-evolving, through mutual adjustment, consensus, and judicial processes. Evolving and monitoring implementation of language policy is a major endeavor of the Language Bureau of the Ministry of Human Resource Development, Government of India. (http://mhrd.gov.in/language-education)

India has a language policy as represented in the Official Languages Act of 1963, Official Languages Rules 1976 (revised in 1987), but it is conspicuously silent on endangered languages. Nonetheless, it stems from the guidelines of the Constitution of India. Article 351 of the constitution of India gives Sanskrit the status of "the primary source language" for many languages including Hindi. According to an unofficial source $75 \%$ of Indians speak Indo-Aryan languages and 20\% speak Dravidian languages and no estimate of another 5\% is available. Every province in India has at least a major language, whether it is official language or English. Most of the present 29 provinces of India have been created on the basis of linguistic homogeneity, 
except a few. The $8^{\text {th }}$ Schedule to the Indian Constitution lists 22 official languages (http://mhrd.gov.in/sites/upload_files/mhrd/files/upload_document/EIGHTH-SCHEDULE.pdf) belonging to heterogeneous language families (see http://mhrd.gov.in/language-education for detailed information) and there are demands to include another 30 languages in the list. It is deplorable that as of now the Govt. of India does not have accurate data on all the languages spoken in India, their present status in terms of vitality, and regional distribution, let alone their history of evolution or extinction. The language policy adopted by the Govt. of India through its 2013 programme called "Scheme for Protection and Preservation of Endangered Languages" (SPPEL) is good to begin with but a brief review of the working of the SPPEL and its methodology for language revitalization, as we shall see, shows it is substantially poor in the face current crisis in which a large number of languages are facing the danger of extinction.

In its mission statement, SPPEL recognizes "the perilous situation of languages spoken by lesser known tribal communities" as alarming and affirms that "Language endangerment is followed by language extinction." While observing that when a language gets extinct, the world view and traditional knowledge of the community concerned perishes, it declares: "Saving and preserving through digital documentation and archiving of these endangered languages of the country is the mission of the SPPEL" (http://www.sppel.org/aims.aspx). As a part of its effort, as we observed earlier, the SPPEL which is being implemented by the Central Institute of Indian Languages (CIIL) has pulled in the Central Universities in India for digital documentation and archiving of languages spoken by less than 10,000 people. As of $30^{\text {th }}$ November, 2017, SPPEL has recognized 117 such languages and the saving and preservation work has been in progress in a few dozen of languages since its inception in 2013. As it states, "The SPPEL has appointed several Principal Investigators (PIs) who are based at Universities or other academic institutions across the country" and "with the CIIL Director's guidance, each PI appoints Resource Persons to work under her/him for a language in a particular area or zone." This is how the SPPEL plans to save more than two hundred endangered languages in India. Undoubtedly, an effective language policy requires good language planning and implementation. No linguist can certainly claim that India's current language policy, with flawed outlooks, can ever be successful in the gigantic task of saving hundreds of endangered languages.

The major shortcomings of India's language policy as regards the endangered languages as well as its flagship scheme are that the approach is purely academic in nature and to use Plato's phrase thrice divorced from reality: (1) No standard uniform methods/techniques are prescribed, (2) No action plan to study and counter the causes of language endangerment, and (3) No formula to involve the marginalized linguistic community. The SPPEL has yet to update the progress in the preservation and documentation work undertaken by the universities. When no governments or linguists will ever contradict the claim of UNESCO that "well-planned and implemented language policies can bolster the ongoing efforts of speaker communities to maintain or revitalize their mother tongues and pass them on to younger generations," it is too 
naïve to say that the efforts of the Govt. of India through its SPPEL will save the endangered languages in India as the policy has clear objectives but doubtful progress. It goes without saying that transparency should be a mirror on the commitment and progress of a centralized agency. However, there is no evidence whether SPPEL has pulled in language research institutes working at national and international levels, such as Living Tongues Institute that has produced over 100 online Talking Dictionaries of endangered languages (https://livingtongues.org/); Bhasa Trust (http://www.bhasharesearch.org/milestones/) which has pioneered the "People's Linguistic Survey of India" movement and has been recognized by the Ministry of Tribal Affairs, Government of India as a Centre of Excellence; Indian Sign Language Research \& Training Centre (ISLRTC), and a host of other institutes that can work in tandem. Lack of adequate planning and coordination raises one question: Is there any politics involved in saving endangered languages?

\section{4. The Politics of Language in India}

Politics and languages are inalienable in India (Sarangi, 2010). Ever since independence in 1947, the Prime Ministers of India have faced complex language crisis (King, 1998; Mitchell, 2009). This state is better understood by the very fact that India does not have a national language though Hindi is an official language, not the official language. Though language rivalry between Hindi and non-Hindi languages has been relegated to history, the claim for No. 1 language status has not. Keeping this in view, the Govt. of India in 2004 declared criteria for Classical Language status and as of today six languages have been conferred with this status: Tamil (2004), Sanskrit (2005), Telugu (2008), Kannada (2008), Malayalam (2013), and Odia (2014), each with written and oral history of more than 1000 years. However, UNESCO has considered Tamil as the only classical language so far. Ethnocentric wars in India are not very uncommon, and they have often led to linguistic rivalry and political rivalry. Politics of language has escalated in recent times as a result of globalization. The war on words has frequently resulted in the war of words and marginalization of one language or the other.

Politics and rhetoric go together (Martin, 2014), and India is no exception. The politics of language in India has strengthened some languages and weakened some others in this country. Formation of states in India dates back even to pre-Independence days. The formation of Odisha (formerly Orissa), the first Indian state (pre-independence) organized on a linguistic basis in 1936 in British India, was a result of Odia language movement. However, the first state to be created along with linguistic line (post-independence) is the Telugu-speaking state of (undivided) Andhra Pradesh in 1953 out of the then Madras State. The political movement on language resulted in consolidation of the 16 northern, Telugu-speaking districts of Madras State into the state of Andhra Pradesh. If we take a close reading of the list of the operating languages in India state-wise, we can understand the linguistic basis of state reorganization, besides the fact that 
major languages in the states are "safe" whereas the indigenous languages are, more often than not, "endangered".

Every affluent linguistic community is self-obsessed with their languages. Spending money for promoting linguistic chauvinism is a trend with the aggressive political representatives of the languages concerned, a phenomenon which has not been studied by linguists. Consequently, the politics of language has focused more on the language rather than the people who speak the language. On the other hand, more lip services are being paid on indigenous languages and, as David Crystal points out in the Preface to his book Language death, "questions are raised by members of indigenous speech communities about the extent to which outside researchers are profiting financially from their plight" (2000, p x). Walsh (2005) has examined the "efforts in language revitalization and documentation and the engagement with Indigenous peoples" and he found "the process is profoundly political". Politics and its offshoots like regionalism, nepotism and corruption are responsible for defective language policy and language planning in India.

A systematic people-friendly framework is the need of the hour to revitalize endangered languages. This paper proposes the PPP model will balance language and politics with equal emphasis on the language and the people who use the language (e.g., indigenous people), and thereby help revitalize the endangered language with social harmony.

\subsection{Religious Conversion}

Religious texts, religious functions, and practices play a crucial role in preservation of languages (Davis, 2015; Ahlers, 2006) and as a corollary religious conversion can often demand the converts to shift language and give the language more priority in which the basic teachings of the main prophet(s) have been recorded. Marginalization of a community can happen after religious conversion (Devy, Davis \& Chakravarty, 2016; Moore \& Galucio, 2016) and the linguistic community dwindles in number and vitality. More often than not, translations into mother tongue from the preached language have often been replaced by learning and using the sacred target language. The converters/missionaries are usually resourceful and as a rule their mission makes use of technology to spread the mission language, as has happened with many tribal community's worlds over by the Christian missionaries. In such a situation, one can fully rule out "the gradual shift to the dominant language in a contact situation" (Sasse 1992, p 22) and in certain areas of India English is slowing or replacing tribal languages. However, some scholars have argued that religious rituals and texts in endangered languages can encourage language revitalization (Davis, 2015). We shall see how PPP can stop forcible conversions in the tribal areas where tribal are exploited due to abject poverty and mass illiteracy.

\subsection{Negative Impact of Globalization on Traditional Culture, Ecology and Languages}


Tribal identity is intrinsically connected with their languages (Sinha, 2005). World over indigenous people have been affected by globalization that has resulted in massive industrialization and corporatization, deforestation and inroads into otherwise sustained cultural communities. The World Bank in its World Bank GRI Index 2017 (p. 30) confirms this global trend:

The [World] Bank recognizes that the identities and cultures of Indigenous Peoples are inextricably linked to the lands on which they live and the natural resources on which they depend. These distinct circumstances expose Indigenous Peoples to different types of risks and levels of impacts from development projects, including loss of identity, culture, and customary livelihoods... As social groups with identities that are often distinct from dominant groups in their national societies, Indigenous Peoples are frequently among the most marginalized and vulnerable segments of the population. As a result, their economic, social, and legal status often limits their capacity to defend their interests in and rights to lands, territories, and other productive resources, or restricts their ability to participate in and benefit from development. (http://pubdocs.worldbank.org/en/596381506698022734/AR17-GRI-Index-2017.pdf )

The Govt. of India welcomed globalization through its new economic policy in 1993. Anthropologists and linguists have found that globalization in India has affected the indigenous communities the most. According to a communiqué of Anthropological Survey of India, Ministry of Culture, Government of India, namely "Globalization: Its Impacts on Indigenous Communities":

According to the Anthropological Survey a total of 4,635 communities are now to be found in India. Out of this total, 'tribal' or Indigenous communities number 732 under globalization. The impact of globalization on the Indigenous communities is manifold, and often they are ones most negatively affected. Under globalization, it is the tribal Indigenous areas that have had to face the attacks of massive developmental projects. Cases of displacement of tribal populations have increased in India. Commercial activities have also introduced alien forces, cultures and influences into the traditionally insulated life and culture of the Indigenous peoples. Deprivation of land and forests are the worst forms of oppression that these people experience. It has resulted in the breakdown of community life and a steady cultural death or 'ethnocide'. The tribal people are exterminated by a process of attrition, through which their lands are taken away, their rivers poisoned, their cultures undermined and their lives made intolerable. Hunters and gatherers, forest produce collectors, fisherfolk, both inland and marine, and the rural artisans are the victims of globalization and modern development through appropriation of people's resources for industrial advancement, especially in association with capitalintensive, machine-oriented technology... Its disturbing impact on family and the drastic 
erosion of traditional social life is a main concern. (http://www.anthropologywa.org/iuaes_aas_asaanz_conference2011/0047.html )

According to the latest census in India (Census 2011), tribal people are 8.2 per cent (21467179) of the total population. There are xyz tribes in India and they are scattered all over India (https://tribal.nic.in/) and they face more or less identical problems, such as health, education, and livelihood. Researchers like Atal (2017), Hasnain (2017), Jaysawal and Saha (2014), and Radhakrishna (2016) have examined the transition of the tribal of India from a hoary past to the cruel realities in the wake of globalization. They conclude that globalization in India has a telltale effect on the tribal as it has enhanced the speed and volume of displacement of tribals, economic exploitation of the poor by the rich, loss of livelihood, endangering of Intellectual Property Rights, migration, and loss of cultural identity. Globalization has not only led to the marginalization of the indigenous people and compromise with their human rights (Thornberry, 2002), but also to language endangerment. Globalization has accelerated the process of linguistic imperialism (Phillipson, 1992).

India is one of the signatories among 150 states to the 1992 Rio Earth Summit, the Convention on Biological Diversity, dedicated to promoting sustainable development, which focuses on the "interlocking of language and ecology in traditional knowledge and its intergenerational transfer" (see http://www.biodiv.org/convention/default.shtml). It also highlights how traditional knowledge/culture is transmitted through language:

Traditional knowledge refers to the knowledge, innovations and practices of indigenous and local
communities around the world. Developed from experience gained over the centuries and adapted
to the local culture and environment, traditional knowledge is transmitted orally from generation
to generation. It tends to be collectively owned and takes the form of stories, songs, folklore,
proverbs, cultural values, beliefs, rituals, community laws, local language, and agricultural
practices, including the development of plant species and animal. (See
http://www.biodiv.org/programmes/socio-eco/traditional//).

As many as 75 tribal groups residing in 18 States and Union Territory of Andaman and Nicober Islands (see https://tribal.nic.in/DivisionsFiles/SwLPVTGs.pdf for details) have been declared as Particularly Vulnerable Tribal Groups (PVTG)s by the Govt. of India. These tribes are characterized by (1) a pre-agriculture level of technology, (2) a stagnant or declining population (3) extremely low literacy, and (4) a subsistence level of economy. The 75 listed PVTG's are found in the states and union territories like this: (a) Odisha (13), (b) Andhra Pradesh (12), (c) Bihar \& Jharkhand (9), (d) Madhya Pradesh \& Chhattisgarh (7), (e) Tamil Nadu (6), (f) Kerala (5), (g) Gujarat (5), (h) West Bengal (3), (i) Maharashtra (3), (j) Karnataka (2), (k) Uttarakhand (2), (l) Rajasthan (1), (m) Tripura (1), (n) Manipur (1), (o) Andamans (All the 4 tribal groups), and (p) Nicobar Islands (1). The detailed list of PVTG's territory-wise can be had (see 
http://www.indiantribalheritage.org/?page id=22029). Much like the PVTG's, their languages too, are endangered, thanks to globalization and other necessary devils(?). So it follows that we need a sociolinguistics of globalization to study and control the impact of globalization on language and culture (Phillipson, 2012; P 407), at least for the indigenous people in India.

The Ministry of Tribal Affairs (https://tribal.nic.in/), a department of Government of India, looks after the affairs of the tribal communities in India, needs to look after the socio-economic development of tribal communities vis-à-vis their cultural and linguistic interests. The MHRD and its agencies/institutions need to work in tandem with the Ministry of Tribal Affairs utilizing the ministry's developments schemes, which are being implemented through 192 Integrated Tribal Development Agencies (ITDAs) and other such agencies for the socio-economic development of tribal communities as well as for safeguarding endangered languages as well. We shall explore if PPP can undo some of the evils of globalization and allied forces and help indigenous communities in safeguarding their ecology, language and culture.

\subsection{Migration and Immigration}

The 2011 Census found as many as 45.36 crore people in India are migrants, which is $37.8 \%$ of total population. Translocation takes place for several reasons including employment and education. Interestingly enough, marriage remains the primary reason for women to migrate to other states, where a wife adopts to her husband's mother tongue. Linguistic communities, mainly tribal population, migrating to other states for work also affects linguistic diversity. Ong and Liu (1994), Milroy (2002) and Kerswill (2006) find that in the continents of Europe and America mass scale migration has always led to language loss and new language formation. In India, migration has affected linguistic diversity like any other country. It is anybody's guess that urbanization and migration for employability from tribal areas to cities has resulted in the decline of tribal languages: one heading in the Times of India "17 of 20 Identified Languages Face Extinction as Migration to Cities Erodes Native Culture" confirms the claim that migration may result in endangering languages. Migration does play a pivotal role in language acquisition and language shift. Adsera and Pytlikova (2012) affirm that the "ability to learn and speak a foreign language might be an important factor in the migration decision" and thus in learning new languages. Coming to India, however, the story is not much different -- migration has increased post-globalization with an alarming speed (Hussain, 2017; Giribabu, 2012). While economic factors have accelerated the process of urbanization and migration in India, migrations have in some cases resulted in engendering and in some other cases endangering languages.

The above assumption has been confirmed by Christopher Moseley, the editor of Encyclopedia of the World's Endangered Languages, in his General introduction to the book: 
The economic factors that lead to language death are undeniably important, but they are not uniform. We can say with some certainty that urbanization is a killer of languages, especially if rapid economic change takes place over one or two generations and attracts the rural poor to urban centres in search of work. Not only does urbanisation fragment families, especially in post-colonial states, where the breadwinner may be constrained to move to the city from a subsistence economy to earn a livelihood in a new major-language environment, but it generally fails to provide an institutional basis for maintenance of the non-local languages within the new urban environment.

Economic factors, however, do not merely attract small linguistic populations to the urban centres and erode the nutrients from the soil of their continued existence; they also contribute to the linguistic invasion of even the most settled speech communities. Increased local and national wealth brings with it the opportunity and the desire to 'plug in' to global communications networks, with all the linguistic baggage that this implies. In the late twentieth and early twenty-first centuries, more than ever, the key to linguistic hegemony lies in the possession of the media.

Economic planning with a view to ensuring a sustainable economy is the concern of all governments. Developmental goals and projects, therefore should take into consideration a holistic assessment of a community development programme under national and state-level schemes. Against this need, we shall examine whether PPP can help stabilize a language or help in language maintenance, which is a situation a "minor" language is used by a speaker, a group of speakers, or a speech community in all spheres of life in

an adverse linguistic and social situation.

\subsection{Poor Digital Presence \& Interactiveness}

A careful reflection on the endangered languages of India makes it clear that these are the ones which suffer poor presence on the internet or the web. One of the major differences between "safe" languages and "endangered languages" is their digital divide - presence and absence on the World Wide Web (WWW). If English counts as the safest language in the world, one of the reasons is its rich digital presence - for a long time English was the first language of the Internet and as of now it occupies more than 40 per cent of the WWW. Chinese, now a safe and dominating language, has of late seen burgeoning growth of internet users. 
In his article "Tackling the Digital Language Divide" published in The Digitalist Magazine (23 Feb., 2017), Simon Davies observes:

Still, of the 6,000-7,000 or so languages in use today, it's estimated only four percent are represented online. It would be nearly impossible to get every single one of those languages online, given that only about half of the world's languages can be written. However, since the UN declared access to the Internet a basic human right, it has become essential that everyone has the ability to use and understand the Internet. It is clear that being able to access to the Internet is not enough alone to put everyone on an equal digital footing; we must all be able to access that Internet in our own language too.

We may not be far from truth if we say that a language is safe if a large number of people use it on the web. Corollary to this premise, we can say that the lack of presence of a language on the web indicate its lack of vitality and therefore endangerment. All the endangered languages in India suffer from poor web presence and little web interaction. What's more, this is state of the languages endangered concerning their use in the social media as well. The chance of revitalization of an endangered language may be possible through its increased use in the social media and internet.

\subsection{Mediocracy}

By 'mediocracy' we mean all the definitions offered by the Urban dictionary: (1) Rule by those who are of average or below average competence; (2) A society in which people with little (if any) talent and skill are dominant and highly influential; (3) A social or administrative system which is like an antithesis to a meritocracy (https://www.urbandictionary.com/define.php? term=mediocracy). Mediocre people in power prefer mediocre people to be in charge of projects. Even if a competent person(s) is/are in charge, pressure groups will bring competent people and viable projects down to the level of mediocrity. This is how most of the plans and projects in India have suffered in absence of sufficient number of strong and competent people either in the planning stage or in the execution, or in both. Mediocracy is the standard rather than deviation in the LR programmes in India.

When it comes to language revitalization efforts, it requires large numbers of linguists and language activists/anthropologists well-trained in language documentation and allied works. It goes without saying that technology can be used for extensive language maintenance and revitalization (Penfield, 2006). The lack of trained personnel having knowledge of linguistic methods, tools and techniques of language preservation, as the SPPEL has admitted, is a handicap on LR programmes. Language In the $21^{\text {st }}$ century when computerized and digital 
multimedia technologies are used for creating new ways to practice and preserve cultural heritage (Scott, 2007, p. 138), mediocre "linguists" in India have left the marginalized communities in lurch. Although governments make policies, they are over-dependent on linguists and language activists for language revitalization. In India, though there is no resource crunch or budgeting problem, acute shortage of resource persons (linguists and language activists) well-versed in the methods, tools and techniques of language revitalization. Not many Indian linguists are known to have brought back a language after the death of a language. Language documentation work India is not fool-proof or hundred per cent free from errors. More and more trained workforce is needed for any LR programme, and the only way is to train a large number of people in LR work. This will no doubt consume much time. However, the involvement of mediocre people, who think LR work as "others' language" (Spears, 2009) in the LR activities cannot be ruled out.

\subsection{Poor Media Control}

Indian mass media has highlighted the catastrophe of language loss. However, the media has failed to pressurize the union, state governments and authorized agencies to update the public about their LR activities and milestones at regular intervals. Absence of strong support for endangered languages within the government and apathy from the opposition parties (as minority languages don't generally qualify to be vote banks) requires the media to take up the non-popular yet public issue of linguistic suicides. The media must not treat language loss as a mere source of sensational news; it must treat language loss or a symptom thereof at par with genocide. The involvement of media in LR activities can certainly enhance the morale of the doomed community, language activists, and the public at large. This will in turn ensure more and more government funding, local (private) funding, and foreign funding to carry out LR activities on a long-term basis.

In the coming sections, we shall explore whether the PPP model/framework can really help language revitalization in India. This paper does not pretend to give a recipe for language preservation, but it intends to help language policy makers, linguists working in the field of language endangerment, scholars studying language loss, educationists planning for reverse language shift (RLS), governments and administrators interested in language maintenance and revitalization, private agencies/institutions and linguistic minority communities working on or interested in combating language attrition. This paper presents PPP as an essential framework for a successful language revitalization program with a view to setting and achieving realistic goals by exploring convergence of top-down and bottom-up approaches. 


\subsection{Public-Private Partnership (PPP) and Language Revitalization}

While noting that there is no single, internationally accepted definition of Public-Private Partnership (PPP), the World Bank defines it in its PPP Reference Guide, Version 3, 2017, as:

"A long-term contract between a private party and a government entity, for providing a public asset or service, in which the private party bears significant risk and management responsibility and remuneration is linked to performance. ... The project functions transferred to the private party - such as design, construction, financing, operations, and maintenance - may vary from contract to contract, but in all cases the private party is accountable for project performance and bears significant risk and management responsibility. PPP contracts typically allocate each risk to the party that can best manage and handle it - risk transfer to the private party is not a goal, but is instrumental for full transfer of management responsibility and for the alignment of private interests with the public interest." (https://pppknowledgelab.org/guide/sections/1-introduction),

PPP does not mean reduced responsibility and accountability of the government (2THEPOINT, October 13, 2017). The principles and practices in PPP are well researched and documented (Yescombe, 2007). The WB and Govt. of India compiled report Public Private Partnership projects in India: Compendium of Case Studies demonstrates that the story of PPP in India is largely a story of success, albeit hiccups here and there. There is a strong case for reviving PPPs in all sectors of governance (Bayliss \& Waeyenberge, 2017).

In the PPP mode the government and private agencies work together to make a project succeed. PPP in India is basically an initiative of the Govt. of India/state government which is a top-down approach that has seen considerable success. The Department of Economic Affairs, Ministry of Finance, Govt. of India maintains a website for dissemination of information on PPP related policy documents, government guidelines, procedures and model documents, institutional frameworks, ongoing projects, etc. to PPP practitioners and researchers. As per the Infrascope Report of the Economist Intelligence Unit, "Evaluating the environment for PPPs in Asia-Pacific 2014", India ranked $1^{\text {st }}$ in the world in "Operational Maturity" for PPP projects, $3^{\text {rd }}$ for subnational PPP activity and $5^{\text {th }}$ overall in terms of having an ideal environment for PPP projects. (https://www.pppinindia.gov.in/). The website provides information about the PPP best practices. The PPP framework has led to successful completion of most of the infrastructure projects implemented in India (www.infrastructureindia.gov.in). Pratap and Chakrabarti (2017) have demonstrated that PPP projects have succeeded in the infrastructure sector in India state-wise. The IMF claims in World Economic Outlook (October 2017) GDP based on PPP, share of world 
(Percent of World), India stands at 7.46. Other sectors, like culture and tourism, have also mooted the use of PPP.

The global management consulting firm McKinsey \& Company recommended the Govt. of India to use public-private partnership (PPP) route for improving health care delivery in India by 2022. The Niti Ayog (formerly the Planning Commission of India), the highest policy making body of the Government of India, and Union Health Ministry have put forward a public-private partnership (PPP) model for the management of healthcare sector with the World Bank as technical partner to transform the sector into success (The Economic Times, July 24 of 2017; Business Line, July 13, 2017) as envisioned in National Heath Policy, 2017 (www.mohfw.nic.in/documents/policy). In his paper "Public-Private Partnership In Healthcare In India: Analysis Of Success", Saxena of IIM Indore, reveals that PPP in healthcare in (2015) ,India has been successful but needs better management. In IndiaPublic Private Partnership (PPP) has "created various success stories whether it is infrastructure sector, agriculture, education or health care sector and the benefits" which have boosted the Indian economy (Dawra \& Sharma, 2016). This researcher agrees with (Agrawal, 2015) that PPP can be revived in all sectors in India.

\subsection{PPP Framework for Language Revitalization}

India has a very organized administrative set up that can be suitable for PPP projects. The country consists of 29 states and 7 union territories. Each state/UT is further divided into districts with an IAS officer as District Collector and Magistrate. Each district is further divided into subdivisions or sub-districts and each sub-division into tehsils/talukas/mandals/circles (names vary across states) and each tehasil into blocks and each block into panchayats and each panchayat into villages and each village into wards. In the urban areas, however, this system is slightly different as in blocks you will find Municipalities/Notified Area Councils and they are subdivided into wards. And each administrative unit has a government and a head (local self governments/state government and central government). With a very well-organized administrative system, India is a most suitable country to carry out public-private partnership projects in a suitable PPP mode if the framework is further integrated with linguistic areas. The concept of linguistic area has been discussed in detail by Masica (1976) and Emeneau (1980), Abbi (1991/1992) and its limitations has been discussed by Campbell (2017). However, before discussing how PPP will be highly effective in reversing language shift and language attrition, we need to have a look at the various PPP modes used in India and elsewhere. 


\begin{tabular}{|c|c|}
\hline \multicolumn{2}{|c|}{ PPP: Modes and Operations } \\
\hline $\begin{array}{l}\text { Schemes and Modalities of } \\
\text { PPP Schemes }\end{array}$ & Modalities \\
\hline $\begin{array}{ll}- & \text { Build-own-operate (BOO) } \\
- & \text { Build-develop-operate (BDO) } \\
- & \text { Design-construct-manage-finance } \\
& \text { (DCMF) }\end{array}$ & $\begin{array}{l}\text { The private sector designs, builds, owns, } \\
\text { develops, operates and manages an asset with no } \\
\text { obligation to transfer ownership to the } \\
\text { government. These are variants of design-build- } \\
\text { finance-operate (DBFO) schemes. }\end{array}$ \\
\hline $\begin{array}{ll} & \text { Buy-build-operate (BBO) } \\
\text { - } & \text { Lease-develop-operate (LDO) } \\
\text { - } & \text { Wrap-around addition (WAA) }\end{array}$ & $\begin{array}{l}\text { The private sector buys or leases an existing asset } \\
\text { from the Government, renovates, modernises, } \\
\text { and/ or expands it, and then operates the asset, } \\
\text { again with no obligation to transfer ownership } \\
\text { back to the Government. }\end{array}$ \\
\hline $\begin{array}{ll}\text { - } & \text { Build-operate-transfer (BOT) } \\
\text { - } & \text { Build-own-operate-transfer (BOOT) } \\
\text { - } & \text { Build-rent-own-transfer (BROT) } \\
\text { - } & \text { Build-lease-operate-transfer (BLOT) } \\
\end{array}$ & $\begin{array}{l}\text { The private sector designs and builds an asset, } \\
\text { operates it, and then transfers it to the } \\
\text { Government when the operating contract ends, or } \\
\text { at some other pre-specified time. The private } \\
\text { partner may subsequently rent or lease the asset } \\
\text { from the Government. }\end{array}$ \\
\hline
\end{tabular}

A misconception that exists among some people is that PPP and privatization are interchangeable concepts. The article "Difference Between Public Private Partnership (PPP) and Privatisation" in 2THEPOINT of October 13, 2017 brings out the difference between PPP and privatization:

Typically, the PPP is not a privatization. At the same time, it cannot be described as partial privatization also. Privatization has generally been defined as a process of shifting the ownership or management of a service or activity, in whole or part, from the government to the private sector. The privatization may be of many forms, which include outsourcing, management contracts, franchise, service shedding, corporatization, disinvestment, asset sales, long-term lease, etc. The key difference between the PPP and privatization is that the responsibility for delivery and funding a particular service rests with the private sector in privatization. The PPP, on the other hand, involves full retention of responsibility by the government for providing the services. In case of ownership, while ownership rights under privatization are sold to the private sector along with associated benefits and costs, the PPP may continue to retain the legal ownership of assets by the public sector. (www.2thepoint.in/difference-public-private-partnership-pppprivatisation/) 
Recent years have witnessed efforts in documentation, maintenance and revival of endangered languages (Carjuzaa, $18 ; 2017$ Child Language Research and Revitalization .Working Group, 2017; Tsunoda, 2006; 29 Grenoble \& Whaley, 2006), but use of PPPs for LR is innovative. The advantages of PPP for language revitalization programmes will be many if done strategically as follows. PPPs should be based on minority linguistic communities with project office, LR Lab, conference hall, media centre with satellite phone, video cameras, voice recorders, machine translation lab, and other special requirement as per the nature and scope of LR in a given community. Financial arrangements should be made between government (local self-government/state government), private party/parties inside/outside the community, and the community representatives as per the modes and modalities of PPP. Highly popular movies in the dominating languages should be dubbed in the endangered language/target language and shown to the people of the community free of cost. A community radio should be installed for user-friendly programmes in various areas, such as agriculture, songs, etc. The folklores in practice should be encouraged and telecast in national and international channels to make the community feel proud of themselves. PPPs will be better placed to identify the strength of a community like their music, painting, hunting style, medicines, etc. which will endear them to the world at large through broadcasts and telecasts. Annual cultural fests should be held and similar other communities should be encouraged to participate in them. Inter-community Dining and Entertainment Fairs should be arranged regularly so that a sense of ethnocentricity will be developed among the community people. If the target language lacks a script, such a script that is suitable to the cultural norms of the people and phonemes of the target language be made. Phonetic data analysis of the endangered language is one of the steps towards LR (Ladefoged, 2003) and PPPs should provide or arrange such facilities. Oral literature should be translated into books, audio cassettes and video cassettes and should be purchased by government and the money be distributed among the community participants. As Himmelmann $(2006, \mathrm{p} 1)$ points out "the core of a language documentation includes audio or video recordings of a communicative event (a narrative, a conversation, etc.)", PPPs should use language technologies to document songs, plays, dances, community rituals, etc. involving the community and organize/sponsor such events. Ecolinguistic tourism through PPP should be in practice so that the economic condition of the community will improve. Involved agencies/personnel need, first of all, to be engaged in a simulated PPP prefeasibility analysis, transaction negotiation, and monitoring exercises after being trained in designing, implementing, and monitoring a PPP program, so that they are capable of applying best practices in conducting financial, economic, and technical feasibility studies prior to the setting up of LR PPPs. Last but least, PPPs should adopt a holistic approach and a detailed, strategic PPP action plan so that they can look after the physical, ecological, financial, cultural, linguistic and spiritual health of a minority linguistic community which will ensure transformation of an endangered language into a safe language. The most important task for a PPP, before and after its formation, is to convince the minority linguistic communities, especially tribal communities, to take agency and save their own language, culture, and ecology from extinction. 


\subsection{Conclusion}

Language death is serious threat to the social, cultural and democratic institutions in India. India's dubious status as the world capital of endangered languages is a major challenge to linguists, linguistics research institutions, and language workers. As desperate diseases require desperate remedies, LR strategies in India should effective language planning, reform in language policy, training and development of language resource persons, establishment of sophisticated state of the art language revitalization labs, and innovative frameworks like PPPs as integration and execution centres, media sensitization, and incentives for language ambassadors. An effective judiciary and a sensible media can also help, and their language can save languages.

\section{References}

Abbi, A. 1991/1992. Edited. India as a Linguistic Area Revisited. Language Sciences 13:2.

Pergamon Press.

Adsera, Alicia \& Pytlikova, Mariola (2012). The role of language in shaping international migration. Discussion paper 6333, IZA.

AGARWAL, M. (2015, Oct). How to revive the PPP model in India? Retrieved 2016, from Business Line: http://www.thehindubusinessline.com/opinion/how-to-revivethe-ppp-modelin-india/article7797268.ece. Retrieved: 14 December, 2017.

Ahlers, J. (2006). Framing discourse: Creating community through native language

use. Journal of Linguistic Anthropology, 16(1), 58-75.

Andresen, C Julie Tetel \& Carter, Phillip M. (2016). Languages in The World: How History, Culture, and Politics Shape Language. Oxford: Wiley \& Sons Inc.

Atal, Yogesh (2017). Indian Tribes in Transition. Routledge.

Atlas of the World's Languages in Danger, UNESCO, 2010, $3^{\text {rd }}$ Edition. 
Austin, P., 2008. 1000 Languages. The Worldwide History of Living and Lost Tongues. London, Thames and Hudson.

Batibo, Herman, M. (2005). Language Death and Decline in Africa: Causes, Consequences and Challenges. Clevedon: Multilingual matters.

-- --- -- (2009). "Poverty as a Crucial Factor in Language Maintenance and Language Death,” in

Wayne Harbert and Sally McConnell-Ginet (eds) Language and Poverty. Volume 141, Clevedon: Multilingual matters.

Bayliss, Kate \& Waeyenberge, Elisa Van (2017). Unpacking the Public Private Partnership

Revival. The Journal of Development Studies. 27 Mar 2017. https://doi.org/10.1080/ 00220388.2017. 1303671

Biddle, N., \& Swee, H. (2012). The relationship between wellbeing and indigenous land,

language and culture in Australia. Australian Geographer, 43(3), 215-232.

Brenzinger, M. (ed.), 2007. Language Diversity Endangered. Berlin, New York, Mouton de Gruyter.

Campbell, L. (2017). Why is it so Hard to Define a Linguistic Area? In R. Hickey (Ed.), The

Cambridge Handbook of Areal Linguistics (Cambridge Handbooks in Language and Linguistics, pp. 19-39). Cambridge: Cambridge University Press. doi:10.1017/9781107279872.003

Carjuzaa, J. (2017). Revitalizing Indigenous languages, cultures, and histories in Montana, across the United States and around the globe. Cogent Education, Volume 4, 2017 - Issue 1.

Census India 2011. Office of the Registrar General \& Census Commissioner, India; Ministry of Home Affairs, Government of India. Available at: http://censusindia.gov.in/ 
Child Language Research and Revitalization Working Group. (2017). Language

documentation, revitalization, and reclamation, Supporting young learners and their communities. Waltham, MA: EDC.

Crystal, D. (2000) Language Death. Cambridge: Cambridge University Press.

Davies, Simon (2017). “Tackling the Digital Language Divide”. The Digitalist Magazine, 23

Feb., 2017: http://www.digitalistmag.com/digital-economy/2017/02/23/tackling-digitallanguage-divide-04918931.

Davies, W. \& Ziegler, E (eds.) (2015). Language Planning and Microlinguistics: From Policy to Interaction and Vice Versa. UK: Palgrave Macmillan.

Davis J. L. (2015) Intersections of Religion and Language Revitalization. In: Brunn S. (eds) The Changing World Religion Map. Springer, Dordrecht

Dawra1, Aarti and Jagtap, Meenal Sharma (2016). Public-Private Partnership (PPP) Role in Infrastructure Development in India in Transportation Sector Advances in Economics and Business Management (AEBM) p-ISSN: 2394-1545; e-ISSN: 2394-1553; Volume 3, Issue 3; April-June, 2016, pp. 327-331

Devy, G. N.; Davis, Geoffrey V. \& Chakravarty, K. K. (eds) (2016). The Language Loss of the Indigenous. India: Routledge.

Difference Between Public Private Partnership (PPP) and Privatisation. 2thepoint https://www.2thepoint.in/difference-public-private-partnership-ppp-privatisation/. Accessed on $28^{\text {th }}$ November, 2017.

Emeneau, M.B. 1980. Language and Linguistic Area. Stanford CA: Stanford University Press. Ethnologue: Languages of the World (2017). https://www.ethnologue.com/guides/howmany- languages. Accessed on $29^{\text {th }}$ November, 2017. 
Giribabu, M. “Globalisation and Labour Migration from India: Some Economic and Social Implications”. Journal of Economic and Social Development, Vol. VIII, No. 1, 2012.

Grenoble, L. and Whaley, L., 2006. Saving languages. An introduction to language revitalization. Cambridge, Cambridge University Press.

Hasnain, Nadeem (2017). Tribal India. Lucknow: New Royal Book Company; 2017 edition. Himmelmann, Nikolaus P. Language documentation: What is it and what is it good for? In Gippert, Jost, Nikolaus P. Himmelmann, and Ulrike Mosel eds 2006. Essentials of language documentation. Berlin: Mouton de Gruyter.

Hussain, Parvaiz (2017). Effect of Globalization on Indian Economy. International Journal of Advance Research and Development. Volume2, Issue1.

Kerswill, Paul (2006). Migration and language. In Klaus Mattheier, Ulrich Ammon \& Peter Trudgill (eds.) Sociolinguistics/Soziolinguistik. An international handbook of the science of language and society, 2nd edn., Vol 3. Berlin: De Gruyter.

King, Robert D. (1998). Nehru and the Language Politics of India Oxford University Press; UK

Krauss, Michael. 1992. The world's languages in crisis. Language 68(1): 4-10.

Ladefoged, Peter. 2003. Phonetic data analysis: An introduction to fieldwork and instrumental techniques. Oxford: Blackwell.

Lalonde, C. E. (2006). Identity formation and cultural resilience in Aboriginal communities. In R. J. Flynn, P. Dudding \& J. G. Barber (Eds.), Promoting resilient development in young people receiving care: International perspectives on theory, research, practice and policy (pp. 52-71). Ottawa: University of Ottawa Press.

LEVI-STRAUSS, C. (1962). The Savage Mind. Paris: Librarie Plon. 
Lewis, M. P., Simons, G. F., \& Fennig C. D. (Eds.). (2013). Ethnologue: Languages of the world (17th ed.). Dallas, Texas: SIL International. Retrieved October 29, 2017. http://www.ethnologue.com.

Lewis, M. Paul (ed.), 2009. Ethnologue: Languages of the World, Sixteenth edition. Dallas, Tex.:SIL International.Online version: http://www.ethnologue.com. Retrieved December 7, 2017.

Loh, J. \& D. Harmon (1986). Biocultural Diversity: threatened species, endangered languages. WWF Netherlands, Zeist, The Netherlands.

MACCORMACK, C. \& STRATHERN, M. (1980) Nature, Culture and Gender. Cambridge: Cambridge University Press.

Martin, J., 2014. Politics and rhetoric: a critical introduction. London: Routledge.

Masica, Colin P. (1976). Defining a Linguistic Area. Chicago: University of Chicago Press.

Milroy, Lesley (2002) “Introduction: Mobility, contact and language change - Working with contemporary speech communities”, in: Journal of Sociolinguistics 6, 3-15.

Mirza A., Sundaram D. (2016) "Harnessing Collective Intelligence to Preserve and Learn Endangered Languages”. In: Vinh P., Barolli L. (eds) Nature of Computation and Communication. ICTCC 2016. Lecture Notes of the Institute for Computer Sciences, Social Informatics and Telecommunications Engineering, Vol 168. Springer, Cham.

Mishra, Prashant (2011). "Linguistic Human Rights and the Tribes in India". Indian Journal of Applied Linguistics, v37 n2 p119-137 Jul-Dec 2011. New Delhi: Bahri Publications.

Mitchell, Lisa. (2009) Language, Emotion, and Politics in South India: The Making of a Mother Tongue. Bloomington: Indiana University Press. 
Moore, Denyy \& Anna Vilacy Galucio (2016). Perspectives for the documentation of Indigenous

Languages in Brazil. In Gabriela Pérez Báez, Chris Rogers, Jorge Emilio Rosés Labrada (eds.) Language Documentation and Revitalization in Latin American Contexts. Volume 295 of Trends in Linguistics. Studies and Monographs [TiLSM]. Walter de Gruyter $\mathrm{GmbH} \& \mathrm{Co} \mathrm{KG}$.

Moore, R. E. (2006). Disappearing, Inc.: Glimpsing the sublime in the politics of access to endangered languages. Language and Communication, 26(3/4) 296-315.

Moseley, C. (ed.), 2007. Encyclopedia of the World's Endangered Languages, New York. Routledge.

Moseley, Christopher, ed. (2010). Atlas of the World's Languages in Danger. Memory of Peoples (3rd ed.). Paris: UNESCO Publishing.

Mufwene, S. (2004) Language birth and death. Annu. Rev. Anthropol. 33, 201-222.

Mufwene, S. S.: 2001. The Ecology of Language Evolution, Cambridge, Cambridge University Press.

-- -- -- (2004) Language birth and death. Annu. Rev. Anthropol. 33, 201-222.

Mühlhäusler, P.: 2003, Language of Environment - Environment of Language. A Course in Ecolinguistics, London, Battlebridge.

Neelmani Jaysawal \& Sudeshna Saha (2014). "Marginalisation of Tribal Communities due to Globalization”. Indian Journal of Dalit and Tribal Studies, Volume-2, Issue-2, July-Dec 2014, pages 37-54.

Nettle, D., \& S. Romaine. 2000. Vanishing Voices: The Extinction of the World's Languages. 
New York: Oxford University Press.

Ong, Paul, and Liu, John M. (1994). U.S. immigration policies and Asian migration, (pp. 45-73).

In Paul Ong, Edna Bonacich \& Lucie Cheng (Eds.), The New Asian Immigration in Los Angeles and Global Restructuring. Philadelphia: Temple University Press.

ORTNER, S.B. (1972). Is Female to Male as Nature Is To Culture? Feminist Studies.[Online] Proquest. p. 5-31.

Penfield, Susan D., 2006. Technology-Enhanced Language Revitalization. Arizona: Arizona Board of Regents.

Phillipson, Robert (1992). Linguistic imperialism. Oxford \& New York: Oxford University Press.

Phillipson, Robert 2012. "How to strengthen the sociolinguistics of globalization: A review article" based on challenges in The sociolinguistics of globalization by Jan Blommaert. Critical Discourse Studies 9(4): 407-414.

PPP Reference Guide Version 3, 2017. Available at: https://pppknowledgelab.org/guide/ sections/1-introduction.

Pratap, Kumar V. \& Chakrabarti, Rajesh (2017). Public-Private Partnerships in Infrastructure. Springer Singapore.

Pretty, Jules \& Sarah Pilgrim (2008). "Nature and Culture”, Issue 250, September/October 2008 Indigenous Intelligence: Diverse Solutions for the 21st Century.

Radhakrishna, Meena ed. (2016), Description for First Citizens: Studies on Adivasis, Tribals, and Indigenous Peoples in India. Oxford India Studies in Contemporary Society. New York: Oxford University Press. 
Report of the High Level Committee on Socio-Economic, Health and Educational Status of Tribal Communities of India. Ministry of Tribal Affairs Government of India May, 2014. www.kractivist.org/wp-content/.../12/Tribal-Committee-Report-May-June-2014.pdf.

Retrieved 18 October 2017.

Rhydwen, Mari. 1998. Strategies for doing the impossible. In Ostler (ed.) Endangered languages: what role for the specialist? 101-6.

Robinson, C.D.W. (1996). Language Use in Rural Development: An African Perspective. Berlin: Mouton de Gruyter.

Romaine, S. (2015). “The Global Extinction of Languages and Its Consequences for Cultural Diversity" IN H.F. Marten et al. (eds.), Cultural and Linguistic Minorities in the Russian Federation and the European Union, Multilingual Education 13. DOI 10.1007/978-3-31910455-3_2.

-- -- -- (2006). Planning for the survival of linguistic diversity. Language Policy 5(2):443-475. -- -- -- (2013). Language endangerment. In Chapelle, C.A. ed. The Encyclopedia of Applied Linguistics. Oxford: Wiley-Blackwell. pp. 1-7.

Salzmann, Z. (1998). Language, Culture and Society. An Introduction to Linguistic Anthropology. USA: Westview Press.

Sarangi, Asha (2010) Language and Politics in India. USA: Oxford University Press. Sasse, Hans-Jürgen (1992). Theory of language death, language decay, and contact-induced 
change: Similarities and differences. In M. Brenzinger (ed.), Language Death: Factual and Theoretical Explorations with Special Reference to East Africa. Berlin: Mouton de Gruyter. 59-80.

Saxena, Nitya (2015). "Public-Private Partnership In Healthcare In India : Analysis Of Success Factor Using Quantitative Content Analysis.” http://vslir.iimahd.ernet.in:8080/xmlui/ bitstream/handle/11718/14115/CMHS_IC-15-030.pdf?sequence=1\&isAllowed=y. Accessed 17 Nov. 2017.

Sayre, A. P. (1999). Africa. Brookfield, Conn: Twenty-First Century Books.

Scott, T. (2007). Student technology projects in a remote First Nations village. In. L.E. Dyson, M. Hendriks \& S. Grant (eds.), Information Technology and Indigenous Peoples (pp. 137140). Hershey, PA: Information Science Publishing.

Sinha, S. (2005). Tribal education in Orissa Linguistic issues. In Tribe Vol. 37 No 1-2.

Speas, Margaret (2009). Someone Else's Language On the Role of Linguists in Language

Revitalization in J. Reyhner \& L. Lockard (eds.). (2009). Indigenous Language

Revitalization: Encouragement, Guidance \& Lessons Learned (pp. 23-36). Flagstaff, AZ:

Northern Arizona University.

Thornberry, P.: 2002, Indigenous peoples and human rights, Manchester, Manchester University Press.

Tsunoda, Tasaku, 2006. Language Endangerment and Language Revitalization. New York: Gruyter GmbH. 
Walsh, Michael 2005. Will Indigenous Languages Survive? The Annual Review of Anthropology,

$$
34: 293-315
$$

Whalen, Douglas. H. \& Gary F. Simons. 2012. Endangered language families. Language 88(1): $155-173$.

World Bank Annual Report 2017 GRI Index (Fiscal Year 2017).

http://pubdocs.worldbank.org/en/596381506698022734/AR17-GRI-Index-2017.pdf.

Accessed on 14 November, 2017.

Wurm, Stephen A. (1991). "Language Death and Disappearance: Causes and Circumstances”.

Diogenes. Volume: 39, issue: 153, page(s): 1-18.

https://doi.org/10.1177/039219219103915302.

Yang, C.D. (2000) Internal and external forces in language change. Language Var. Change 12, pp 231-250.

Yescombe, E.R. 2007. Public-Private Partnerships: Principles of Policy and Finance. Oxford: Butterworth-Heinemann.

Atal, Yogesh (2017). Indian Tribes in Transition. Routledge.

Bayliss, Kate \& Waeyenberge, Elisa Van (2017). Unpacking the Public Private Partnership Revival. The Journal of Development Studies. 27 Mar 2017. https://doi.org/10.1080/ 00220388.2017. 1303671

Devy, G. N.; Davis, Geoffrey V. \& Chakravarty, K. K. (eds) (2018). The Language Loss of the Indigenous. Routledge India; 1 st edition. 
Report of the High Level Committee on Socio-Economic, Health and Educational Status of Tribal Communities of India. Ministry of Tribal Affairs Government of India May, 2014. www.kractivist.org/wp-content/.../12/Tribal-Committee-Report-May-June-2014.pdf. Retrieved 18 December 2018.

Mohanty, Seemita. Impact of English and Major Indian Languages on the Tribal Languages of Western Odisha. Gyan Publishing House (2 November 2015)

Chaudhary, S.N. Primitive Tribal (PVTGs) of Central India: Then and Now. Concept Publishing Company Pvt. Ltd. (2016) 